\title{
Concordance between expected and observed bacilloscopy results of clinical forms of leprosy: A 6-year retrospective study in Recife, State of Pernambuco, Brazil
}

\author{
Ana Amélia Lucena Cavalcanti ${ }^{[1]}$, Norma Lucena-Silva ${ }^{[2]}$, Ulisses Ramos Montarroyos ${ }^{[3]}$ \\ and Patrícia Maria Cavalcanti Carneiro de Albuquerque ${ }^{[3]}$
}

[1]. Centro Integrado de Saúde Amaury de Medeiros, Secretaria de Saúde de Pernambuco, Recife, PE. [2]. Centro de Pesquisas Aggeu Magalhães, Fundação Oswaldo Cruz, Recife, PE. [3]. Núcleo de Docência em Saúde, Faculdade Maurício de Nassau, Recife, PE.

\section{ABSTRACT}

Introduction: Operational classification of leprosy based on the number of skin lesions was conceived to screen patients presenting severe forms of the disease to enable their reception of a more intense multidrug regimen without having to undergo lymph smear testing. We evaluated the concordance between operational classification and bacilloscopy to define multibacillary and paucibacillary leprosy. Methods: We selected 1,213 records of individuals with leprosy, who were untreated (new cases) and admitted to a dermatology clinic in Recife, Brazil, from 2000 to 2005, and who underwent bacteriological examination at diagnosis for ratification of the operational classification. Results: Compared to bacilloscopy, operational classification demonstrated 88.6\% sensitivity, $76.9 \%$ specificity, a positive predictive value of $61.8 \%$, and a negative predictive value of $94.1 \%$, with $80 \%$ accuracy and a moderate kappa index. Among the bacilloscopy-negative cases, $23 \%$ had more than 5 skin lesions. Additionally, $11 \%$ of the bacilloscopy-positive cases had up to 5 lesions, which would have led to multibacillary cases being treated as paucibacillary leprosy if the operational classification had not been confirmed by bacilloscopy. Conclusions: Operational classification has limitations that are more obvious in borderline cases, suggesting that in these cases, lymph smear testing is advisable to enable the selection of true multibacillary cases for more intense treatment, thereby contributing to minimization of resistant strain selection and possible relapse.

Keywords: Leprosy. Classification. Paucibacillary. Multibacillary.

\section{INTRODUCTION}

Leprosy is a public health problem in 32 countries with Brazil ranking the second in total number of cases, behind India. In Brazil, the State of Pernambuco presents the third most high incidence rate, which represented 32.8 new cases per 100,000 inhabitants in 2008. Moreover, it was also high the incidence rate of 12.9 in population under 15 years ${ }^{1}$.

Leprosy is an infectious disease whose etiologic agent, Mycobacterium leprae, is a slow growing intracellular bacillus, that affects mainly the skin and peripheral nerves, leading to few infiltrative lesions with discrete loss in sensitivity up to disseminated lesions with significant and disabling sequels ${ }^{2-6}$.

The transmission of $M$. leprae occurs through the droplets from the upper respiratory tract or microscopic lesion on skin or mucous membranes of the infected individuals into healthy individuals. The proliferation and survival of the bacilli in macrophages and Schwann infected cells depends on the patient's immune response, taking 2-5 years or more to induce clinical expression. Paucibacillary (PB) cases have a small number of bacilli in the body and are regarded as resistant to the infection compared to multibacillary (MB) cases, which has a high rate of bacillus growth ${ }^{2,3,7,8}$.

Address to: Ana Amélia Lucena Cavalcanti. Rua Dezenove de Novembro 240/101-A, Conjunto Residencial Nacional, Madalena, 50610-240 Recife, PE, Brasil.

Phone: 5581 3227-4039; 5581 8777-1961

e-mail: norma.lucena@hotmail.com

Received in 04/08/2011

Accepted in 14/12/2011
The clinical diagnosis of leprosy is based on morphological and topographic criteria of the lesions, associated with changes in skin sensitivity and thickening and/or pain of peripheral nerves, being the most affected nerves the radial, ulnar, median, fibular and posterior tibial. The microbiological confirmation is given by the presence of acid-resistant bacilli in the lymph smear, the gold standard for diagnosis4.

According to the Madrid classification, defined at the VI International Leprosy Congress in 1953, leprosy is presented in four different clinical forms: indeterminate leprosy (IL), tuberculoid leprosy (TL), borderline or dimorphic leprosy (BL) and lepromatous or Virchowian leprosy (LL), based on the increment of the degree of infectivity represented by the increase in the number of bacilli, injuries and damaged nerves, and growing commitment of the cellular immune system for destruction of $M$. leprae $e^{3,9,10}$. IL is characterized by the presence of hypo chromic skin lesions with loss of thermal sensitivity and without neural involvement. TL has well-defined hypo chromic skin lesions, with loss of thermal, touch and painful sensitivity, there is neural involvement, but the smear is negative. LL has multiple skin lesions, morphologically variable and rich in viable bacilli, accompanied by loss of skin sensitivity; it is infectious and often shows involvement of other organs. BL represents the evolution of the TL into LL, the morphology of the lesion and the presence of bacilli vary widely, favoring tissue damage and physical disabilities ${ }^{2,3,8,9}$.

The operational classification for therapeutic purposes consists of grouping patients with more than five skin lesions in multibacillary leprosy (MB) and those with up to five lesions in paucibacillary leprosy (PB). This classification was suggested to simplify classification for treatment purposes of leprosy in places lacking laboratory physical 
structure, equipment, supplies and technical personnel trained to carry out an appropriate bacteriological examination ${ }^{11-13}$. Multibacillary leprosy corresponds to the BL and LL clinical forms, while PB corresponds to the IL and TL forms; the MB with a positive load of bacilli in lymph smears are kept in multidrug therapy for a period of twelve months, while the PB with a negative load of bacilli in lymph smears for a period of only six months ${ }^{4}$.

Since 1995, the World Health Organization (WHO) recommended no obligation of the microbiological confirmation of the leprosy for allocation of the patients to appropriate treatment regimens ${ }^{8}$. In 2002, according recommendation of the WHO, the Ministry of Health of Brazil, no longer refers to the number of affected nerves for classification of leprosy for the purpose of multidrug therapy decision ${ }^{2,3}$. Currently, the baciloscopy for leprosy is considered as a complementary test for the identification of $\mathrm{PB}$ and $\mathrm{MB}$ cases of difficult clinical classification, differential diagnosis with other dermatological diseases associated with neurologic disorders or suspected cases of relapse. Thus, the smear-positive case is defined as MB regardless of the number of injuries; on the other hand the diagnosis is not excluded with the negative result on the baciloscopy 2,7 .

In the present study we aim to verify the accuracy of the operational classification of leprosy, and the agreement between the operational classification defined by the number of skin lesions and the results of the baciloscopy in new cases of leprosy.

\section{METHODS}

\section{Study design and population}

This is a retrospective cross-sectional study conducted in the Dermatological Clinic of the Centro Integrado de Saúde Amaury de Medeiros (CISAM) of the University of Pernambuco, a reference centre in the care of leprosy in Recife, Northeastern of Brazil. The study population was comprised of individuals with leprosy, untreated, admitted to the Dermatology Clinic of CISAM from 2000 to 2005, who underwent bacteriological examination at diagnosis for ratification of the operational classification. It was excluded relapse, reactional leprosy and patients who did not undergo sputum examination at diagnosis.

\section{Data collection}

A total of 1,213 new cases of leprosy were identified among 1,660 reviewed records of patients diagnosed with leprosy from 2000 to 2005. It was used a pre-defined questionnaire for collection of clinical, epidemiological and laboratorial information of new cases of leprosy in the medical records. To compare the data along the period of study, the criterion for the operational classification of leprosy used here is related solely to the number of skin lesions, because from 2002 the neural involvement was not a criterion for classification.

\section{Statistical analysis}

The data collected from medical records were entered into Excel 2007 worksheet. The accuracy of the operational classification was calculated using the Epi info version 6.04. The concordance between the operational classification and the result of sputum examination was determined by the index kappa.

\section{Ethical considerations}

The Ethics Committee of the CISAM under the registration number 036/10 approved this work.

\section{RESULTS}

Medical records of 1,213 leprosy patients with ages ranging from 3 to 93 years were reviewed. Of these, $53.3 \%$ were adults of working age (between 16 to 45 years) and $12.4 \%$ under the age of 15 years. There was no difference on gender distribution.

The most prevalent clinical form was TL diagnosed in $50.4 \%$ of cases, followed by BL with $34.9 \%$. The IL clinical form was less prevalent with only $3.9 \%$ of cases. The operational classification, divided the cases in similar amounts of paucibacillary (54.3\%) and multibacillary (45.7\%) leprosy. Most (70.3\%) of cases were smearing negative. Details of the characteristics of the study population are shown in Table 1.

TABLE 1 - Characteristics of the study population.

\begin{tabular}{lcc}
\hline Characteristics & Number & Percentage \\
\hline Gender & & \\
male & 607 & 50.1 \\
female & 606 & 49.9 \\
\hline Age (years) & & \\
$0-15$ & 150 & 12.4 \\
16-30 & 346 & 28.5 \\
$31-45$ & 301 & 24.8 \\
$46-60$ & 249 & 20.5 \\
$\geq 61$ & 167 & 13.8 \\
\hline Baciloscopy & & \\
positive & 360 & 29.7 \\
negative & 853 & 70.3 \\
\hline Clinical form & & \\
IL & 47 & 3.9 \\
TL & 612 & 50.4 \\
DL & 423 & 34.9 \\
VL & 131 & 10.8 \\
\hline Operational classification & & \\
paucibacillary & 659 & 54.3 \\
multibacillary & 554 & 45.7 \\
\hline Total & 1,213 & 100.0 \\
\hline IL: indeterminate leprosy; TL: tuberculoid leprosy; BL: bordeline leprosy; L: lepromatous leprosy. \\
\hline
\end{tabular}

Of the 516 multibacillary cases, $95.2 \%$ had LL or BL clinical forms, however $4.4 \%$ of the cases were TL and $0.4 \%$ IL cases (Table 2). Regarding the 697 paucibacillary cases, $93.4 \%$ cases presented IL or TL clinical forms, but $6.6 \%$ of the BL cases were classified as paucibacillary.

On the other hand, of the 853 cases with negative lymph smears, $77 \%$ had up to five skin lesions and were classified by both methods as paucibacillary leprosy. Likewise, the 360 cases with smear positive, $88.6 \%$ had more than five lesions and were classified as multibacillary leprosy (Table 3). Regarding the cases of disagreement, according to both operational and microbiological criteria, $23 \%$ of cases had negative baciloscopy and more than five skin lesions, and $11.4 \%$ of cases had positive baciloscopy, but had up to five lesions. 
The observed agreement was $80.4 \%$, which corresponds to the kappa index of 0.582 or moderate agreement between both criteria (Table 4).

TABLE 2 - Correlation between leprosy classification according the number of skin lesions and clinical form stratified by the baciloscopy status.

\begin{tabular}{|c|c|c|c|c|c|c|}
\hline \multirow[b]{3}{*}{ Clinical form } & \multicolumn{6}{|c|}{ Number of skin lesion } \\
\hline & \multicolumn{2}{|c|}{$M B(>5)$} & \multicolumn{2}{|c|}{$\mathrm{PB}(\leq 5)$} & \multicolumn{2}{|c|}{ Total } \\
\hline & $\mathrm{n}$ & $\%$ & $\mathrm{n}$ & $\%$ & $\mathrm{n}$ & $\%$ \\
\hline (Baciloscopy positive) & 319 & 88.6 & 41 & 11.4 & 360 & 29.7 \\
\hline TL & 2 & 18.2 & 9 & 81.8 & 11 & 3.0 \\
\hline$B L$ & 199 & 86.1 & 32 & 13.9 & 231 & 64.2 \\
\hline $\mathrm{LL}$ & 118 & 100.0 & 0 & 0.0 & 118 & 32.8 \\
\hline $\mathrm{IL}$ & 0 & 0.0 & 0 & 0.0 & 0 & 0.0 \\
\hline (Baciloscopy negative) & 197 & 23.1 & 656 & 76.9 & 853 & 70.3 \\
\hline $\mathrm{TL}$ & 21 & 3.5 & 580 & 96.5 & 601 & 70.5 \\
\hline$B L$ & 161 & 83.9 & 31 & 16.1 & 192 & 22.5 \\
\hline $\mathrm{LL}$ & 13 & 100.0 & 0 & 0.0 & 13 & 1.5 \\
\hline$\underline{\mathrm{IL}}$ & 2 & 4.3 & 45 & 95.7 & 47 & 5.5 \\
\hline Total & 516 & 42.5 & 697 & 57.5 & 1,213 & 100.0 \\
\hline
\end{tabular}

IL: indeterminate leprosy; TL: tuberculoid leprosy; BL: borderline leprosy; LL: lepromatous leprosy.

TABLE 3 - Concordance between the operacional classification of leprosy and the baciloscopy results.

\begin{tabular}{|c|c|c|c|c|c|c|}
\hline \multirow[b]{3}{*}{ Operational classification } & \multicolumn{6}{|c|}{ Baciloscopy } \\
\hline & \multicolumn{2}{|c|}{$\mathrm{MB}(+)$} & \multicolumn{2}{|c|}{ PB (-) } & \multicolumn{2}{|c|}{ total } \\
\hline & $\mathrm{n}$ & $\%$ & $\mathbf{n}$ & $\%$ & $\mathbf{n}$ & $\%$ \\
\hline Multibacillary (>5 skin lesions) & 319 & 88.6 & 197 & 23.1 & 516 & 42.5 \\
\hline Paucibacillary (up to 5 skin lesions) & 41 & 11.4 & 656 & 76.9 & 697 & 57.5 \\
\hline Total & 360 & 29.7 & 853 & 70.3 & 1,213 & 100.0 \\
\hline
\end{tabular}

MB: multibacillary leprosy; PB: paucibacillary leprosy.

TABLE 4 - Diagnostic test evaluation of the operational classification of leprosy.

\begin{tabular}{lcc}
\hline Parameter & Estimate (\%) & Lower-Upper 95\% Cls \\
\hline Sensitivity & 88.61 & $(84.91-91.49)$ \\
Specificity & 76.91 & $(73.96-79.61)$ \\
Positive predictive value & 61.82 & $(57.56-65.91)$ \\
Negative predictive value & 94.12 & $(92.12-95.63)$ \\
Diagnostic accuracy & 80.38 & $(78.05-82.52)$ \\
Kappa & 0.5822 & $(0.5281-0.6364)$ \\
\hline
\end{tabular}

MB: multibacillary leprosy; PB: paucibacillary leprosy.

\section{DISCUSSION}

The operational classification of leprosy into paucibacillary or multibacillary according to the number of skin lesions is simple and feasible in areas of difficult access to slit skin smear examination. The stratification of the patient by bacillary load allows adjustment of the drug regimen, thus acting in relapse prevention, and also in interrupting transmission.

In this study, we estimated the accuracy of the operational classification in relation to baciloscopy in $80 \%$, similar to that reported by Crippa and colleagues (82\%) and also by Gallo and colleagues $(84 \%)^{12,13}$. Our results showed a moderate agreement
( $K=0.58)$, while Gallo and colleagues found a good agreement analyzing 837 patients ( $\mathrm{K}=0.68)$.

Regarding the study population, the prevalence of the disease in Recife differed from other Brazilian regions that show a discrete increase of prevalence $(55 \%-65 \%)$ in males ${ }^{13,14}$. Although the average age of patients was similar across regions, draws attention to the high prevalence of cases in children under 15 years in Recife $(12 \%)$ similar to that of Manaus (11\%), but in disagreement with that reported in Uberaba, which is only $2 \%$, suggesting the importance of intradomiciliary transmission in the current scenario of leprosy in the cities of North and Northeast of the country ${ }^{13,15}$.

The proportion of paucibacillary cases was high in Recife (64\%) as in Manaus (67\%) and in Maranhão (41\%) where the leprosy burden is high, and contrasted with that observed in Rio de Janeiro (27\%) and Uberaba (13\%) where the prevalence of leprosy is lower ${ }^{12-15}$. The high proportion of paucibacillary cases may reflect an improvement on clinical detection of new cases in a high endemic area. On the other hand, it is also possible that differences on clinical form found in patients from different geographic areas mean the non-homogeneous distribution of strains with different degrees of virulence or better adapted to the host, but this would require a molecular epidemiology study to determine strains distribution in the country.

The non obligation of microbiological confirmation by microscopy was one decision of the health authorities, which favors the early treatment of leprosy. Furthermore, we showed that laboratory confirmation of leprosy was possible in only $30 \%$ of cases in Recife, similar to the rate of detection in Manaus (28\%) and Maranhão (41\%) but less than that found in Rio de Janeiro (78\%) and in Uberaba $(60 \%)^{12-15}$.

The operational classification presented a sensitivity of $88.6 \%$ and a specificity of $76.9 \%$ almost similar to that reported in different study populations, which range from $73.6 \%$ to $89.6 \%$ and from $83.8 \%$ to $85.6 \%$, respectively ${ }^{12,13}$. This methodology gave a reasonable negative predictive value of $94.1 \%$, but a low positive predictive value of $61.8 \%$ (Table 4).

With sensitivity below the expected, the operational classification allowed $11 \%$ of misclassification of multibacillary cases according to the baciloscopy, which would induce these cases to receive a shorter and less intense treatment regimen, a risk factor for relapse. Classification errors of $2.7 \%, 10.4 \%$ and $26.4 \%$ have been reported by health services in São Paulo, Rio de Janeiro and Manaus respectively ${ }^{11-13}$. Most of the discordant cases were of borderline clinical form, which in our study represented approximately $35 \%$ of the total cases, which would be advisable to have the baciloscopy to adjust the treatment regimen. The observation reported here provides evidences to health managers for improving the actions of the Leprosy Control Program, especially in Primary Care, regarding the evaluation criteria for the conduct of diagnostic smear, classification and definition of therapeutics in leprosy, to minimize the occurrence of relapse, for greater control of the disease transmission.

\section{ACKNOWLEDGMENTS}

We thank the administrative personnel from the Centro Integrado de Saúde Amaury de Medeiros for helping during the patient data collection. We are especially grateful to Dr lara Pessoa Sant'Anna for her comments and suggestions. 


\section{CONFLICT OF INTEREST}

The authors declare that there is no conflict of interest.

\section{ABSTRACT IN PORTUGUESE}

\section{Concordância entre os resultados observados e esperados da forma clinica da hanseníase de acordo com a baciloscopia: um estudo retrospectivo de seis anos em Recife, Estado de Pernambuco, Brasil}

Introdução: A classificação operacional da hanseníase baseada no número de lesões de pele foi concebida para selecionar pacientes que apresentam formas graves da doença para receber regime terapêutico mais intenso com múltiplas drogas sem o exame de baciloscopia da linfa. Nós avaliamos a concordância entre a classificação operacional e a baciloscopia para a definição de hanseníase multibacilar e paucibacilar. Métodos: Nós selecionamos 1.213 registros de indivíduos com hanseníase não tratada (casos novos), atendidos em um Ambulatório de Dermatologia, em Recife, Brasil, no período de 2000 a 2005, que foram submetidos a exame bacteriológico ao diagnóstico para a ratificação da classificação operacional. Resultados: Comparando com a baciloscopia, a classificação operacional baseada no número de lesões cutâneas mostrou sensibilidade de $88,6 \%$, especificidade $76,9 \%$, valor preditivo positivo de $61,8 \%$ e valor preditivo negativo de $94,1 \%$, com uma precisão de $80 \%$ e um moderado índice kappa. Entre os casos com baciloscopia negativa, $23 \%$ tinham mais de cinco lesões de pele, recebendo um tratamento mais intensivo. Além disso, $11 \%$ dos casos baciloscopia positiva tinham até cinco lesões, o que induziriam casos multibacilares de serem tratados com hanseníase paucibacilar se a classificação operacional não tivesse sido confirmada pela baciloscopia. Conclusões: Concluímos que a classificação operacional tem limitações mais visíveis nos casos borderline, sugerindo que, nestes casos, o esfregaço seria aconselhável por permitir que os verdadeiros casos multibacilares fossem selecionados para um tratamento mais intenso, contribuindo para minimizar a seleção de cepas resistentes e uma possível recidiva.

Palavras-chaves: Hanseníase. Classificação. Paucibacilar. Multibacilar.

\section{REFERENCES}

1. Ministério da Saúde. Sistema de Informação de Agravos de Notificação (SINAN) [Internet]. Brasília: Ministério da Saúde. Secretaria de Vigilância Sanitária. [Cited
2011 October 14]. Available from: http://tabnet.datasus.gov.br/cgi/deftohtm. exe?idb2009/d0206.def/.

2. Ministério da Saúde. Secretaria de Políticas de Saúde. Coordenação de Dermatologia Sanitária. Guia para o controle da hanseníase. Brasília: Editora do Ministério da Saúde; 2002.

3. Ministério da Saúde. Secretaria de Políticas de Saúde. Departamento de Atenção Básica. Hanseníase: atividades de controle e manual de procedimentos. Brasília: Editora do Ministério da Saúde; 2001.

4. Ministério da Saúde. Secretaria de Atenção a Saúde. Departamento de Atenção Básica. Vigilância em saúde: dengue, esquistossomose, hanseníase, malária, tracoma, tuberculose, Brasília: Editora do Ministério da Saúde; 2007.

5. Garbino JA. Manejo Clínico das diferentes formas de comprometimento da neuropatia hansênica. Hansen Int 1998; 98:93-99.

6. Thangaraj RH, Yawalkar SJ. La lépre pour les médecins et al personnel para-médical. $3^{\text {rd }}$ ed. Balê Suisse: Ciba Geigy; 1988.

7. Talhari S, Neves RG, Oliveira MLW, Penna GO. Introdução, agente infeccioso, transmissão, cultura, inoculação, aspectos laboratoriais, patogenia e diagnóstico. In: Talhari S, Neves RG, editors. Hanseníase. $4^{\text {th }}$ ed. Manaus: Editora Lorena, 2006. p. 15-19.

8. Ministério da Saúde. Secretaria de Vigilância em Saúde. Departamento de Vigilância Epidemiológica. Guia de procedimentos técnicos: baciloscopia em hanseníase. Brasília: Editora do Ministério da Saúde; 2010.

9. Sampaio SAP, Castro RM, Rivitti E. Dermatologia básica. 3a ed. São Paulo: Livraria Editora Artes Médicas Ltda; 1983.

10. Souza CS. Hanseníase: Formas clínicas e diagnóstico diferencial. Anais do Simpósio de Hanseníase - Ribeirão Preto: Medicina 1997; 30:325-334.

11. Andrade VLG, Moreira TA, Avelleira JCR, Marques AB, Bayuona M. Paucibacilar ou Multibacilar? Uma contribuição para os serviços de saúde. Hans Int 1996; 21:6-13.

12. Gallo MEN, Ramos Junior LAN, Albuquerque ECA, Nery JAC, Sales AM. Alocação do paciente hanseniano na poliquimioterapia: correlação da classificação baseada no número de lesões cutâneas com os exames baciloscópicos. An Bras Dermatol 2003;78:415-424.

13. Crippa ILF, Schettini AP, Pennini SN, Shettini MC, Rebello PFB. Correlação clínica laboratorial baseada em dados secundários dos casos de hanseníase atendidos no período de 01/2000 a 03/2001 na Fundação Alfredo da Matta, Manaus - AM, Brasil. An Bras Dermatol 2004; 79:547-554.

14. Lima LS, Jadão FRS, Fonseca RNM, Silva Junior GF, Barros Neto RC. Caracterização clínica-epidemiológica dos pacientes diagnosticados com hanseníase no município de Caxias, MA. Rev Bras Clin Med 2009; 7:74-83.

15. Miranzi SSC, Pereira LHM, Nunes AA. Perfil epidemiológico da hanseníase em um município brasileiro, no período de 2000 a 2006. Rev Soc Bras Med Trop 2010; 43:62-67. 